\title{
Akselerasi covid-19 pada proses pembelajaran di era pendidikan 4.0
}

Fathirma'ruf Fathirma'ruf*), M. Nur Imansyah, Asmedy Asmedy

Program studi Pendidikan Teknologi Informasi, STKIP Yapis Dompu, Nusa Tenggara Barat, Indonesia

\begin{tabular}{l} 
Article Info \\
\hline Article history: \\
Received Jun $09^{\text {th }}, 2021$ \\
Revised Jul $15^{\text {th }}, 2021$ \\
Accepted Aug $27^{\text {th }}, 2021$ \\
\hline
\end{tabular}

\section{Keyword:}

Akselerasi Covid-19

Era pendidikan 4.0

Kesulitan belajar di masa pandemi

\begin{abstract}
The development of technology in the world of education has given rise to a new paradigm of learning and teaching, which was previously carried out conventionally by switching to the use of information technology, Limited means and use of technology have become an important issue in meeting the demands of education in the 4.0 era, since the Schwab Clause and the World Economic Forum declared Fourth Industrial Revolution, since then technology has penetrated into the world of education, but in fact educators at several educational institutions until before the Covid-19 Pandemic were still reluctant to use technology as an effective teaching and learning tool. This research is a descriptive study that aims to summarize related to the facts that occur in the learning process in the Covid-19 pandemic situation. The transfer of the learning process to online mode forces all parties to take part in ensuring the continuity of learning during the pandemic, including the Government. Here, the Ministry of Education and Culture provides support through help and policy in supporting the learning process; besides that, technology provides for education also takes part in improving their technology services to learn for educators and students; as well as educational institutions, practitioners, teachers, and lecturers to respond positively to this support by increasing individual competence and making the best use of these learning tools.
\end{abstract}

(C) 2021 The Authors. Published by IICET

This is an open access article under the CC BY-NC-SA license (https://creativecommons.org/licenses/by-nc-sa/4.0)

\section{Corresponding Author:}

Fathirma'ruf Fathirma'ruf,

STKIP Yapis Dompu, Nusa Tenggara Barat

Email: fathir.ntb@gmail.com

\section{Pendahuluan}

Sejak Klaus Schwab dan Forum Ekonomi Dunia mendeklarasikan kedatangan Revolusi Industri Keempat, berbagai pembahasan muncul akan hal tersebut, (Lee et al., 2018) dalam tulisannya mengatakan bahwa Era Industri 4.0 merupakan era dimana terjadinya perpaduan antara teknologi, dimensi fisik, biologis, menjadi satu kesatuan yang sulit untuk dibedakan. (Putrawangsa and Hasanah, 2018) menggambarkan tentang kesatuan tersebut kepada beberapa orang yang dapat saling bertukar informasi secara langsung dengan bantuan teknologi digital tanpa harus berada pada lokasi dan waktu yang sama baik secara fisikis maupun biologis, Kemudahan seperti yang digambarkan tersebut merupakan salah satu keberman-faatan teknologi informasi yang secara masif terjadi pada berbagai sektor dalam kehidupan manusia, termasuk pada sektor pendidikan, hal tersebut dianggap sebagai ciri dimulainya masa industri 4.0. Dalam buku evaluasi revolusi industri 4.0 yang dirilis oleh Klaus Schwab (Effoduh, 2016) mengatakan bahwa tatanan industri 4.0 juga ditandai dengan perubahan revolusioner oleh Internet seluler di mana-mana; keberadaan mesin dan sensor yang mendukung segala bentuk aktivitas manusia dengan bentuk yang lebih kecil, kuat serta konsep dan 
model pembelajaran buatan yang mengadopsi (artificial Intellegence) sebagai teknologi pembelajaran daru dalam dunia pendidikan.

Dalam artikelnya (Harto, 2018) mengatakan bahwa Terintegrasinya teknologi dalam kehidupan adalah bentuk Kemajuan yang disebut para ilmuan sosial sebagai era disrupsi, era yang dimana seluruh sektor merasakan transformasi digital, tidak terkecuali pada sektor ekonomi, politik maupun pendidikan, (Lase, 2016) pada era yang ditandai oleh perkembangan konektivitas jaringan selular, sistem digital, Artificial Intelligance dan berbagai media virtual ini semakin konvergennya hubungan diantara manusia, mesin dan berbagai sumber daya lainnya, Perubahan yang dianggap sebagai perkembangan zaman ini tidak terhindarkan oleh siapapun, oleh karenanya dibutuhkan persiapan sumber daya manusia yang serius terkait dengan kompetensi teknologi informasi agar dapat bersaing secara global. Dalam artikelnya (Hermann et al., 2016) mengatakan bahwa pendidikan menjadi salah satu indicator penentu bagi suatu negara dalam menghadapi era disrupsi, pendidik yang memiliki kemampuan beradaptasi yang baik dengan perkembangan teknologi adalah pendidik yang selalu siap dalam menghadapi tantangan global. Dalam hal ini, baik pada tingkatan sekolah dasar maupun pendidikan tinggi harus memiliki paradigma baru terakait dengan Konsep dan model pembelajaran yang berbasis pada literasi data, teknologi dan sumber daya manusia.

Era disrupsi menuntut pendidik agar memiliki kompetensi yang tinggi sehingga dapat menghasilkan lulusan yang bersaing, selain itu era ini juga telah menjadikan pendidikan sebagai indicator penentu dalam merespon tantangan revolusi industri 4.0, yang dalam realisasinya membutuhkan keselarasan antara manusia dan teknologi agar dapat melahirkan peluang-peluang yang kreatif dan inovatif dalam mencapai visi baru dunia pendidikan, dimana peserta didik didorong tidak hanya memiliki keterampilan dan pengetahuan tetapi juga dapat mengidentifikasi sumber belajar berbasis teknologi agar dapat mempelajari keterampilan dan pengetahuan tersebut secara individu/ otodidak, Pendidikan 4.0 tidak hanya menuntut kualitas SDM pendidik tapi juga SDM peserta didik, karena hanya dengan cara tersebut jenjang pendidikan dasar sampai pendidikan tinggi dapat beradaptasi terhadap perkembangan Revolusi Industri 4.0 (Fisk, 2017), Dalam pendidikan, teknologi mengambil peran pada terciptanya jenis dan model pembelajaran baru (Warsita, 2017) yang bercirikan pada pendekatan system, tersedianya sumber belajar yang begitu luas, serta berorientasi pada instruksional individu peserta didik (Mukminan, 2012). Teknologi digital yang menjadi ciri utama pendidikan 4.0 mampu memberi warna baru dalam proses pembelajaran karena intensitas pelaksanaanya dapat berlangsung tanpa terhambat oleh ruang dan waktu (Noor, 2019), dalam dukungannya terhadap perkembangan era revolusi industry 4.0 teknologi tidak serta merta menjadi solusi bagi sebagian pendidik, terutama pendidik yang berada di wilayah bagian timur Indonesia, hal ini dibuktikan oleh maraknya artikel yang terpublikasi pada jurnal nasional maupun internasional dengan topic bahasan terkait dengan strategi peningkatan kompetensi pendidik dalam menghadapi era pendidikan 4.0, perkembangan teknologi pada dunia pendidikan menghasilkan pergeseran paradigma baru terhadap cara belajar yang dilakukan secara konvensional menuju pada cara belajar yang berbasis teknologi informasi (Arifin \& Setyawan, 2012).

Sejak ditetapkannya Corona Virus (Covid-19) sebagai wabah dengan status Darurat Kesehatan Global oleh Badan Kesehatan Dunia (WHO) memaksa pemerintah untuk mengeluarkan berbagai kebijakan demi memastikan stabilnya sektor kesehatan, ekonomi, sosial, budaya, pendidikan dan sektor lainnya. Salah satu kebijakan yang nyata dirasakan oleh masyarakat adalah kebijakan jaga jarak fisik dan sosial oleh setiap individu yang dilakukan secara serempak demi membatasi penularan Covid-19 (Chaeruman, 2020), indikasi jaga jarak fisik dan sosial pada sektor pendidikan diawal penyebaran Covid-19 ini bermakna ditiadakannya proses pembelajaran secara tatap muka (Konvensional) baik pada tingkatan sekolah maupun perguruan tinggi (Aji, 2020), dalam kebijakannya pemerintah mengalihkan semua kegiatan pembelajaran tatap muka ke proses pembelajaran daring dengan pemanfaatan sarana belajar berbasis LMS (Learning Management System) (Giatman, Siswati and Basri, 2020),

Pengalihan proses pembelajaran dari konvensional ke daring tentu dihadapkan dengan banyak persoalan, Dalam tulisannya (Atsani, 2020) mengatakan bahwa perubahan metode pembelajaran dari konvensi-onal menjadi online bukanlah pekerjaan yang mudah dan sederhana, pada beberapa sekolah yang terdapat di pedesaan memiliki masalah yang lebih kompleks dibandingkan sekolah yang berada di perkotaan, selain beberapa guru tidak pernah dibekali pelatihan terkait dengan penggunaan sarana belajar berbasis LMS (Learning Management System) seperti Edmoodo, Google Classroom, dan Moodle, proses pembelajaran pun terhambat oleh ketersediaan sarana dan prasarana seperti Laptop, Smartphone, Kuota Internet, dan tidak meratanya akses jaringan telekomunikasi yang stabil untuk mengikuti proses pembelajaran secara Daring.

Penelitian ini bertujuan untuk mengungkap fakta-fakta terkait dengan Kesulitan belajar dimasa pandemi Covid-19; respon pemerintah melalui aturan dan kebijakan; serta respon dan dukungan dari penyedia Teknologi untuk pendidikan dalam mengatasi kesulitan proses pembelajaran dimasa Pandemi Covid-19. 


\section{Metode}

Metode yang digunakan dalam penelitian ini adalah metode deskriptif. Dalam tulisannya (Darmadi, 2011) Penelitian yang dilakukan secara deskriptif bertujuan untuk memberikan gambaran secara sistematis dan tepat sasaran terkait dengan fakta dan karateristik dari objek atau subjek yang hendak diteliti Studi literatur merupakan teknik yang digunakan dalam penelitian ini untuk memperoleh data maupun informasi yang berkaitan dengan tema yang sedang dibahas, beberapa kajian yang mendukung diantaranya: berbagai kajian literatur tentang tantangan para pendidik serta kondisi pendidikan di era revolusi industri 4.0, integrasi teknologi dalam mendukung pendidikan di era pendidikan 4.0, transformasi media pembelajaran dimasa pandemi, kesulitan dan adaptasi pendidik/ peserta didik dalam menghadapi perkembangan teknologi, serta beberapa kajian tentang aturan maupun kebijakan dari pemangku kepentingan dalam mendukung keberlangsungan pendidikan dimasa pandemi Covid-19. Untuk memperoleh informasi - informasi tersebut peneliti mengadopsi dan melakukan kajian secara mendalam dari berbagai sumber diantaranya: buku, naskah berita, maupun artikel ilmiah terbaru yang terpublikasi pada jurnal internasional serta nasional bereputasi dan disajikan secara deskriptif untuk memperoleh kesimpulan baru terkait dengan akselerasi Covid-19 terhadap proses pembelajaran di era Pendidikan 4.0.

\section{Hasil dan Pembahasan}

\section{Kesulitan Belajar dimasa Pandemi}

Kesulitan belajar yang dialami oleh peserta didik merupakan hambatan dalam pencapaian potensi akademik, yang dalam pengertian lain peserta didik tidak dapat belajar sebagaimana mestinya, sehingga terjadinya kesukaran dalam menerima dan menyerap pembelajaran secara maksimal sehingga berdampak pada rendahnya kompetensi dan prestasi yang dicapai oleh peserta didik, selain itu kesulitan belajar juga dapat menimbulkan keputusasaan bagi peserta didik dalam melanjutkan studi pada jenjang yang sedang ditempuh, dengan demikian, kesulitan belajar dapat dimaknai sebagai kondisi dimana peserta didik mengalami penurunan motivasi belajar yang ditimbulkan oleh gangguan eksternal maupun internal dari dalam dirinya (Subarkah and Salim, 2021). Pandemi Covid-19 merupakan salah satu Gangguan eksternal yang dihadapi oleh peserta didik maupun dunia pendidikan pada umumnya, pembatasan aktivitas dilingkungan sekolah menjadikan proses pembelajaran tidak dapat berjalan sebagaimana mestinya.

Kebijakan jaga jarak fisik dan social pada sector pendidikan memaksa pembelajaran dilangsungkan secara daring, yang dalam implementasinya ditemuai kesulitan oleh berbagai kalangan akademisi (baik pendidik maupun peserta didik), Pada beberapa institusi pendidikan, kesulitan dimaksudkan kepada implikasi dari ketidakberhasilan pendidikan dalam memanfaatkan teknologi pembelajaran sebagai sarana belajar yang efektif, ketidak efektifan pembelajaran dinilai sebagai rendahnya kualitas belajar yang dapat berdampak pada terjadinya stress akademik, dimana peserta didik dianggap tidak mampu menghadapi berbagai tuntutan dalam proses pembelajaran yang sedang dilalui (Barseli, Ifdil and Nikmarijal, 2017), Hasil penelitian yang dilakukan (Harahap, 2020) bahwa pada jenjang pendidikan tinggi sebanyak 300 peserta didik yang menjadi sampel penelitian memenuhi kriteria stress tinggi sebesar 13\%, sedang $75 \%$ dan rendah sebesar $12 \%$ disebabkan oleh berbagai factor seperti sumberdaya akses internet yang terbatas, ketiadaan perangkat elektronik pendukung, keterbatasan pengetahuan dalam pemanfaatan sumber belajar, serta distribusi tugas dari pendidik yang tidak terkontrol selama proses pembelajaran daring dimasa pandemi covid-19.

Selain stress akademik yang dirasakan oleh peserta didik, beberapa pendidik juga mengalami kesulitan pada penggunaan teknologi informasi baik hardware seperti laptop, dan smartphone, maupun pada sisi software Learning management system (LMS), kesulitan yang dirasakan oleh pendidik dapat dipastikan karena ketidaksiapan pendidik dalam memanfaatkan teknologi sebagai sarana belajar terkait dengan pengelolaan proses, evaluasi, dan pengembangan media berbasiss elektronik, (Budiman, 2020) mengatakan bahwa beberapa pendidik pada berbagai jenjang pendidikan diwilayah Indonesia bagian timur khususnya Nusa Tenggara Barat, baik sekolah maupun pendidikan tinggi masih menggunakan teknik belajar yang konvensional tanpa melibatkan teknologi pembelajaran sehingga berdampak pada rendahnya kemampuan berpikir Kritis dan Kreatif peserta didik. (Walter, 2006) mengatakan bahwa berkembangnya pendidikan pada berbagai Negara tidak lepas dari pemanfaatan teknologi informasi sebagai sarana belajar dan proses evaluasi yang terstandar, selain itu (Nur et al., 2020) juga mengatakan bahwa pemanfaatan teknologi dalam pendidikan jarak jauh seperti e-learning akan memberi kepraktisan dalam menunjang kegiatan belajar dan mengajar, dalam tulisannya (Suhardjono, 2007) juga mengatakan bahwa Teknologi pembelajaran adalah solusi alternative dalam mengatasi permasalahan pada dunia pendidikan diabad ke-21 selain itu teknologi pembelajaran juga dianggap evektif dalam mendukung peserta didik untuk menemukan sumber belajar sendiri dalam mengembangkan potensi dan cara berpikirnya (Thiagarajan, 1974). 


\section{Respon Pemerintah terhadap Kesulitan Belajar dimasa Pandemi}

Dalam merespon kesulitan belajar dimasa pandemi pemerintah benar-benar dituntut untuk mengopti-malkan teknologi pembelajaran sebagai sarana belajar agar dapat menjamin keberlangsungan proses pembelajaran pada segala jenjang, teknologi pembelajaran atau yang dikenal dengan istilah (Instructional technology) merupakan bidang yang berperan dalam mengoptimalkan proses pembelajaran pada semua jenjang maupun jenis pendidikan dengan cara memadukan berbagai sumber belajar, diantaranya, manusia, materi, media, perangkat pembela-jaran, lingkungan, alat, cara maupun teknik belajar secara sistematik, (Permenpan No: PER/2/M. PAN/3 /2009). Pembelajaran jarak jauh yang dilakukan secara daring merupakan implementasi dari teknologi pembelajaran yang secara nyata dapat menjadi solusi alternative ketika terjadi bencana alam seperti pandemi covid-19 (Syarifudin, 2020), Kesulitan yang dihadapi oleh pendidik maupun peserta didik dalam implementasi pembelajaran jarak jauh dimasa pandemi mendorong pemerintah agar mendukung proses pembelajaran melalui beberapa kebijakan, dan realisasi program diantaranya:

- Melalui Siaran Pers Kemdikbud Nomor : 272 /sipres/A6/IX/2020 Menteri Pendidikan dan kebudayaan (Mendikbud) Republik Indonesia meresmikan kebijakan bantuan Kuota data internet bagi pendidik dan peserta didik dalam menjalani pembelajaran jarak jauh, kebijakan tersebut adalah bentuk dukungan pemerintah dalam menjamin keberlangsun-gan proses pembelajaran ditengah pandemi covid-19.

- Melalui Siaran Pers Kemdikbud Nomor: 366 /sipres/A6/XI/2020 Mendikbud RI juga resmi memperkuat semangat Pendidik dan Tenaga Kependi-dikan non pegawai negeri sipil melalui Bantuan subsidi Upah, kebijakan tersebut dalam upaya melindungi, mempertahankan dan meningka-tkan ekonomi pendidik dan tenaga kependi-dikan pada satuan pendidikan dimasa pandemi Covid-19.

- Melalui Siaran Pers Kemdikbud Nomor: 422 /Sipres/A6/XII/2020 Mendikbud RI telah mempersiapkan Program Belajar dari Rumah (BDR) melalui tayangan dari stasiun televisi Nasional untuk beberapa jenjang pendidikan diantaranya PAUD, SD, SMP dan SMA/SMK sederajat, program dimaksudkan untuk memenuhi kompetensi literasi, serta penguatan karakter siswa yang dianggap tidak maksimal karena keterbatasan interaksi tatap muka disekolah.

- Melalui Siaran Pers Kemdikbud Nomor: 054/SIPRES/A6/III/2020 Mendikbud RI merilis sistem informasi pembelajaran jarak jauh secara daring yang dapat diakses melalui laman http://belajar.kemdikbud.go.id, selain berbasis website, layanan tersebut juga telah dimutakhirkan dengan penggunaan platform android "Rumah Belajar" dengan beberapa fitur unggulan seperti: sumber belajar bagi peserta didik, Kelas Digital, Laboratorium Maya, dan beberapa Soal Evaluasi yang diperuntuhkan bagi pendidik dan peserta didik jenjang PAUD, SD, SMP dan SMA/SMK sederajat, selain itu Kemdikbud juga telah mengem-bangkan program pembelajaran GTK secara daring melalui laman: https://gurubelajardanberbagi.kemdikbud.go.id/ layanan tersebut merupakan gerakan kolaborasi antara pemerintah, Guru, Komu-nitas dan Penggerak Pendidikan dalam berbagi ide, pikiran melalui aksi webinar, dan sharing perangkat/bahan ajar secara daring dalam upaya mening-katkan kompetensi guru dalam menghadapi era pembelajaran 4.0.

Beberapa Kebijakan seperti yang disampaikan diatas merupakan upaya pemerintah dalam menjamin keberlangsungan pendidikan di Indonesia, yang secara keseluruhan diarahkan agar kegiatan pembelajaran dapat secara maksimal dilakukan diluar sekolah, selain dari dukungan tayangan melalui media elektronik (stasiun televisi), Pembelajaran jarak jauh menjadi salah satu alternatif dalam melangsungkan kegiatan belajar dan mengajar ditengah pembatasan sosial (Subarkah and Salim, 2021), dalam pemilihan platform sebagai sarana pembelajaran, pendidik dapat memanfaatkan berbagai media yang dianggap mampu menunjang proses pembelajaran, seperti WhatsApp, Telegram, Instagram, Zoom, dan beberapa media lainnya (Anzar and Mardhatillah., 2017).

\section{Dukungan Penyedia Teknologi untuk pendidikan}

Dalam Siaran Pers yang sama Nomor: 054/sipres/A6/III/2020 Mendikbud RI juga menyampaikan bahwa selain mengembangkan sendiri sistem pembelajaran jarak jauh yang dapat dimanfaatkan secara gratis oleh pendidik maupun peserta didik, Kemdikbud mengapresiasi dukungan dari penyedia teknologi pendidikan, seperti Google Indonesia melalui Google Suite For Education, yang merupakan layanan aplikasi berbasis Cloud maupun Website yang diperuntuhkan untuk mendukung proses pembelajaran agar pendidik dan peserta didik dapat tetap merasakan nuansa layaknya kelas nyata yang terselenggara karena dimungkinkan pendidik dan peserta didik dapat berinteraksi secara langsung seperti diskusi dan saling berkomentar melalui pesan teks, rekaman suara, maupun dengan layanan conference melalui system (Raharjo et al., 2019), keberadaan teknologi informasi menjadi alternative penting dalam mendorong upaya-upaya untuk meningkatkan kualitas dan mutu pembelajaran (Setiawati, 2019).

Tidak hanya Google, beberapa penyedia teknologi pembelajaran lain juga berpartisipasi dalam menjamin keberlangsungan pendidikan di Indonesia seperti Kelas Pintar (melalui laman http://kelaspintar.id), 
Microsoft, Quipper (melalui laman: https://www.quipper.com/-id/school/teachers/), Ruangguru (melalui laman: $\quad$ https://sekolahonline.ruangguru.com), Sekolahmu (melalui laman: https://www.sekolah.mu/tanpabatas), Microsoft Indonesia, (melalui laman: https://microsoft.com/idid/education/products/office) dan Zenius (melalui laman: https://zenius.net/belajar-mandiri), merupakan layanan belajar online yang menyediakan system tata kelola pembelajaran jarak jauh yang dapat digunakan oleh pendidik dan atau peserta didik sebagai sarana pembelajaran, selain menjadi sarana interaksi antar guru dan siswa dalam proses pembelajaran layanan-layanan tersebut juga memberikan pengalaman belajar tersendiri secara individu kepada siswa dengan kecukupan fasilitas seperti materi pelajaran yang berbasis video, audio, animasi, e-book, latihan soal, tryout ujian, layanan privat, layanan bimbingan belajar dan berbagai layanan pembelajaran lainnya.

Konten yang disajikan pada masing-masing layanan telah disesuaikan dengan kurikulum nasional pada masing-masing jenjang pendidikan (Setiawati, 2019), keberadaan sekolah online melalui layanan-layanan belajar seperti yang disebutkan diatas menjadi sarana penyampaian informasi dan ilmu pengetahuan yang baik bagi pendidik dan peserta didik dimasa pandemic covid-19 tanpa dibatasi oleh jarak dan waktu (Nurchaili, 2010).

\section{Simpulan}

Hasil kajian dalam penelitian ini dapat disimpulkan bahwa Pandemi Covid-19 dianggap mampu mengakselerasi proses Pembelajaran di era pendidikan 4.0, bentuk akselerasi yang dimaksud tergambar pada respon pemerintah RI dalam beberapa dukungannya melalui aturan dan kebijakan, diantaranya: 1) Bantuan Kuota data internet bagi Pendidik dan peserta didik pada masing-masing jenjang pendidikan, 2) Bantuan Subsidi Upah Bagi Pendidik dan tenaga Kependidikan Non Pegawai Negeri Sipil, 3) Terdapatnya Program Belajar dari Rumah Melalui tayangan pada stasiun televisi Nasional, 4) Terdapatnya system informasi pembelajaran daring berbasis Website maupun Android; selain itu dukungan juga muncul dari Penyedia/ pengembang teknologi pendidikan seperti Google Indonesia, Kelas Pintar, Microsoft Quipper, Ruang Guru, Sekolahmu,Microsoft Indonesia dan Zenius, berpartisipasi dalam meningkatkan layanan agar dapat memaksimalkan proses pembelajaran yang berlangsung di Indonesia.

Institusi Pendidikan, Praktisi, Guru, maupun Dosen masing-masing merespon positif dukungan tersebut dengan pemanfaatan sarana belajar yang tersedia secara maksimal serta dituntut untuk meningkatkan kompetensi melalui Pelatihan-pelatihan yang tersedia secara daring agar dapat menjamin pendidikan di Indonesia berjalan secara maksimal. Dukungan yang berupa bantuan maupun kebijakan dari Pemerintah RI maupun pihak swasta yang menjadi mitra Kemdikbud telah menjadi alternative penting dalam menjamin keberlangsungan proses pembelajaran dimasa pandemic, Agar dapat memaksimalkan proses pembelajaran dimasa pandemic Covid-19 pendidik harus dapat memahami bantuan dan dukungan dari berbagai pihak, seperti pemerintah dan pengembang teknologi pembelajaran Terkait dengan sumber belajar yang berbasis teknologi informasi

\section{Referensi}

Aji, R. H. S. (2020). Dampak Covid-19 pada Pendidikan di Indonesia: Sekolah, Keterampilan, dan Proses Pembelajaran. SALAM: Jurnal Sosial Dan Budaya Syar-I, 7(5), 395-420. https://doi.org/10.15408/sjsbs.v7i5.15314

Atsani, L. G. M. Z. (2020). Transformasi Media Pembelajaran Pada Masa Pandemi Covid-19. Al-Hikmah: Jurnal Studi Islam, 1(1), 82-93. Retrieved from http://ejournal.kopertais4.or.id/sasambo/index.php

Barseli, M., Ifdil, I., \& Nikmarijal, N. (2017). Konsep Stres Akademik Siswa. 5(2005), 143-148.

Budiman, F. (2020). Pengembangan Perangkat Pembelajaran Konstruktivistik Model Teaching With Analogies (TWA) Pada Matakuliah Database Management System (DBMS) Untuk Meningkatkan Kemampuan the Development of Constructivistic Learning Tool of Teaching With Analogy (TWA). Jurnal Teknologi Informasi Dan Ilmu Komputer (JTIIK), 7(5), 1051-1060. https://doi.org/10.25126/jtiik.202072388

Chaeruman, U. A. (2020). Ruang Belajar Baru dan Implikasi terhadap Pembelajaran di Era Tatanan Baru. $\begin{array}{llll}\text { Jurnal Teknologi Pendidikan, } & \text { 08(01), }\end{array}$ https://doi.org/http://dx.doi.org/10.31800/jtp.kw.v8n1.p142--153

Effoduh, J. O. (2016). Book Evaluation of The Fourth Industrial Revolution by Klaus Schwab. The Transnational Human Rights Review, 3(1), 1-10. Retrieved from http://digitalcommons.osgoode.yorku.ca/thr/vol3/iss1/4\%0AThis

Giatman, M., Siswati, S., \& Basri, I. Y. (2020). Online Learning Quality Control in the Pandemi Covid-19 

Era
Indonesia.
Journal of Nonformal
Education,
$6(2)$
$168-175$. https://doi.org/http://dx.doi.org/10.15294/jne.v6i2.25594

Harahap, A. C. P. (2020). Analisis Tingkat Stres Akademik Pada Mahasiswa Selama Pembelajaran Jarak Jauh Dimasa Covid-19. Biblio Couns : Jurnal Kajian Konseling Dan Pendidikan, 3(1), 10-14. https://doi.org/10.30596/bibliocouns.v3i1.4804

Harto, K. (2018). Tantangan Dosen Ptki Di Era Industri 4.0. Jurnal Tatsqif, 16(1), 1-15. https://doi.org/10.20414/jtq.v16i1.159

Hermann, M., Pentek, T., Otto, B., \& Pentek, T. *. (2016). Design Principles for Industrie 4.0 Scenarios: A Literature Review Competence Center Corporate Data Quality (CC CDQ) View project Industrial Data Space View project Design Principles for Industrie 4.0 Scenarios: A Literature Review. 49th Hawaii International Conference on System Sciences (HICSS), (September 2016), 16. https://doi.org/10.13140/RG.2.2.29269.22248

Lase, D. (2016). Pendidikan di Era Revolusi Industri 4.0. Journal Sunderman, 1(1), 28-43. Retrieved from 10.1109/ITHET.2016.7760744

Lee, M. H., Yun, J. H. J., Pyka, A., Won, D. K., Kodama, F., Schiuma, G., ... Zhao, X. (2018). How to respond to the Fourth Industrial Revolution, or the second information technology revolution? Dynamic new combinations between technology, market, and society through open innovation. Journal of Open Innovation: Technology, Market, and Complexity, 4(3). https://doi.org/10.3390/joitmc4030021

Mukminan. (2012). Penguatan Jati diri Profesi Pengembang Teknologi PembelajaranDan Berbagai Permasalahannya. FIS/Pascasarjana - UNY, 0-10.

Noor, F. A. (2019). Kompetensi Pendidik MI di Era Revolusi Industri 4.0. Elementary, 7(2), 251-278.

Nur, M. R. O., Wicaksono, G. R. K., Nasukha, A. U., \& Kusumaningrum, W. R. (2020). Pemberdayaan Guru Dalam Masa New Normal Dalam Penggunaan Media Pembelajaran Digital Di Sdn Taman Agung 4 Secara Daring. ABDIPRAJA (Jurnal Pengabdian Kepada Masyarakat), 1(1), 1. https://doi.org/10.31002/abdipraja.v1i1.3200

Putrawangsa, S., \& Hasanah, U. (2018). Integrasi Teknologi Digital Dalam Pembelajaran Di Era Industri 4.0. Jurnal Tatsqif, 16(1), 42-54. https://doi.org/10.20414/jtq.v16i1.203

Suhardjono, 2007. Mengaktifkan Peran Teknologi Pendidikan guna Meningkatkan Kompetensi Pedagogik Guru, Makalah Seminar Pengembangan Teknologi Pem-belajaran, yang diselenggarakan oleh Pustekom Diknas, Bogor, 6-7 Nopember 2007

Syarifudin, A. S. (2020). Impelementasi Pembelajaran Daring Untuk Meningkatkan Mutu Pendidikan Sebagai Dampak Diterapkannya Social Distancing. Jurnal Pendidikan Bahasa Dan Sastra Indonesia Metalingua, 5(1), 31-34. https://doi.org/10.21107/metalingua.v5i1.7072

Thiagarajan, S. (1974). Instructional development for training teachers of exceptional children. In A sourcebook.

Warsita, B. (2017). Peran dan Tantangan profesi pengembang teknologi pembelajaran pada pembelajaran $\begin{array}{lllll}\text { Abad 21. Kwangsan: Jurnal Teknologi Pendidikan, } & 5(2), & 77--90 .\end{array}$ doi:https://doi.org/10.31800/jtp.kw.v5n2.p77--90 